\title{
On the Reproductive Diapause in the Predatory Ladybird Cheilomenes sexmaculata (Fabricius, 1781) (Coleoptera, Coccinellidae)
}

\author{
S. Ya. Reznik $a, b, *$ A. N. Ovchinnikov $a, b$, A. A. Ovchinnikova ${ }^{b}$, \\ O. S. Bezman-Moseyko ${ }^{b}$, and N. A. Belyakova ${ }^{a}$ \\ a All-Russia Institute of Plant Protection, Russian Academy of Sciences, Pushkin, St. Petersburg, 196608 Russia \\ ${ }^{b}$ Zoological Institute, Russian Academy of Sciences, St. Petersburg, 199034 Russia \\ *e-mail:reznik1952@mail.ru
}

Received January 14, 2021; revised January 19, 2021; accepted January 19, 2021

\begin{abstract}
The ability to enter reproductive diapause was experimentally studied in females of the laboratory population of the predatory ladybird Cheilomenes sexmaculata originated from individuals collected in Nepal in a region of subtropical monsoon climate. The experiment included 12 regimes, i.e. combinations of 2 temperatures (20 and $24^{\circ} \mathrm{C}$ ), 3 photoperiods (day lengths of 10,12, and $14 \mathrm{~h}$ ), and 2 diets (the green peach aphid Myzus persicae and eggs of the grain moth Sitotroga cerealella). Females with undeveloped ovaries and well developed fat body were considered as diapausing. The proportion of diapausing females was significantly dependent only on the temperature being $0.8 \%$ at $24^{\circ} \mathrm{C}$ and $7.4 \%$ at $20^{\circ} \mathrm{C}$. Although found in only a small fraction of the studied population, the ability to enter reproductive diapause (as suggested by literature data) was probably an important prerequisite for Ch. sexmaculata spread northwards to the temperate zone.
\end{abstract}

Keywords: diapause, temperature, photoperiod, variation, Cheilomenes sexmaculata, Coccinellidae

DOI: $10.1134 / \mathrm{S} 0013873821010012$

Facultative diapause anticipatory induced by environmental cue factors and ensuring survival during adverse periods is one of the most important seasonal adaptations of insects (Tauber et al., 1986; Danks, 2007; Tougeron, 2019). Winter diapause that is usually induced in insects of the temperate and arctic zones by short light day and / or low temperature results in a decrease in metabolism intensity, in an arrest of development or reproduction, in an increase in cold resistance, and in other changes which are necessary for successful overwintering of most insect species. Therefore, the process of induction of winter diapause is strictly controlled by natural selection ensuring precise adaptation to the specificity of the local climate (Danilevsky, 1961; Zaslavsky, 1984, 1996; Denlinger, 2002; Saunders et al., 2002; Saulich and Volkovich, 2004). In insects inhabiting the subtropical zone, where the winter decrease in temperature and corresponding worsening of the environmental conditions are poorly expressed, the selective value of wintering adaptations is not as high as in the temperate and arctic zones. Nevertheless, facultative winter diapause induced by short day and low temperature is also recorded for many subtropical insects, although it is not as deep and stable as in insects from the temperate and arctic zones. Moreover, often not only diapause intensity but also diapause frequency decreases: even under the most "strong" combination of diapause-inducing factors it is induced in only a small proportion of individuals. It is well known that this individual variability in the ability to diapause is not only important for the population survival during the extreme seasons but also serves as an essential prerequisite for the spreading to the regions with colder climate (Saulich, 1999; Saulich and Volkovich, 2004).

The object of our study, the predatory ladybird Cheilomenes sexmaculata (Menochilus sexmaculatus) (Fabricius, 1781) (Coleoptera, Coccinellidae), is widely 
distributed in the tropical and subtropical regions of Southern Asia (Afghanistan, Pakistan, India, Indonesia, Philippines, etc.) and Australia (Iftikhar et al., 2018) and at present is spreading northward up to central Japan (Kawakami et al., 2016, 2017). This widely distributed polyphagous species is well known as an important agent for biological control of various sucking insect pests (Pandi et al., 2012; Iftikhar et al., 2018) and, therefore, the main aspects of its biology have been thoroughly studied (Campbell et al., 1980; Omkar et al., 2005; Pandi et al., 2012; Wang et al., 2013; Mirhosseini et al., 2015; Zhao et al., 2015; Singh et al., 2016; Iftikhar et al., 2018). In particular, it was shown that the time of female maturation depends not only on temperature, but also on photoperiod (Wang et al., 2013). The day length also influences the mean rate of preimaginal development (Singh et al., 2016), but the ability to enter reproductive diapause was not considered in these studies. Phenological observations of $C h$. sexmaculata populations conducted under natural conditions in Japan, near the northern limit of the species range suggested that adults overwintered in reproductive diapause (Kawakami et al., 2016, 2017), although this was not verified by special laboratory experiments. Transfer to the short day conditions also did not induce diapause in ovipositing females of the laboratory strain originated from individuals collected in Pakistan (Campbell et al., 1980).

We made an attempt to induce reproductive diapause in females of the laboratory population of $\mathrm{Ch}$. sexmaculata originated from individuals collected in Nepal in a region of the subtropical monsoon climate.

\section{MATERIALS AND METHODS}

The experiments were conducted with the laboratory population of $C h$. sexmaculata originated from 30 individuals collected in May 2013 in Nepal, in the environs of Sauraha $\left(27.5848^{\circ} \mathrm{N}, 84.5038^{\circ} \mathrm{E}, 189 \mathrm{~m}\right.$ asl). Sauraha has a subtropical monsoon climate: the average temperatures of December-January and May-August are about 16 and $29^{\circ} \mathrm{C}$, correspondingly; the dry season with the mean monthly precipitation of less than $20 \mathrm{~mm}$ lasted from November to March (data from https://ru.climate-data.org/).

For several years the ladybirds were reared in Biocontrol Laboratory of All-Russia Institute of Plant Protection on the wheat aphid Schizaphis graminum Rond. (Hemiptera, Aphididae) at a temperature of $20-25^{\circ} \mathrm{C}$ and day length of $18 \mathrm{~h}$. The experiments were conducted in Laboratory of Experimental Entomology (Zoological Institute RAS). Before the study the ladybirds were for 1 or 2 generations reared at a temperature of $24^{\circ} \mathrm{C}$ and day length of $14 \mathrm{~h}$; larvae and adults were fed on the green peach aphid Myzus persicae (Sulz.) reared on bean Vicia faba L. seedlings. Larvae and pupae of individuals which were used in the experiments were reared under the same conditions.

At the beginning of the experiment (no more than $24 \mathrm{~h}$ after emergence) Ch. sexmaculata adults were weighed on electronic scales with the accuracy of $0.1 \mathrm{mg}$ and then, in pairs (male and female), were placed in plastic Petri dishes $60 \mathrm{~mm}$ in diameter and $15 \mathrm{~mm}$ high. Then all the dishes were evenly distributed between 12 experimental treatments, i. e. combinations of 2 temperatures $\left(20\right.$ and $24^{\circ} \mathrm{C}$ ), 3 photoperiods (day lengths of 10, 12 and $14 \mathrm{~h}$ ), and 2 diets: (1) larvae and adults of the green peach aphid on a bean seedling or (2) frozen eggs of the grain moth Sitotroga cerealella (Oliv.) (Lepidoptera, Gelechiidae) glued with a 30\% water solution of sugar to a piece of hard paper and a plastic tube filled with water and plugged with a cotton ball. The relative air humidity was the same in all the treatments of the experiment (about 70\%); the food was always provided in excess. All dishes were daily observed to record the beginning of oviposition. At the end of the experiment ( 10 days at $24^{\circ} \mathrm{C}$ and 15 days at $20^{\circ} \mathrm{C}$ ) all the females were weighed again and then dissected. The age of females at dissection was calculated based on the results of earlier studies: under the optimal conditions, by this time most individuals start to lay eggs (Campbell et al., 1980; Omkar et al., 2005; Wang et al., 2013; Mirhosseini et al., 2015; Zhao et al., 2015). The state of ovaries was evaluated with the simple scale: "developed" (follicles are wider than germarium; mature oocytes are well visible) or "undeveloped" (only germarium is visible, follicles are absent or barely noticeable); the fat body was also evaluated as "developed" or "undeveloped."

Thus, for each survived female, the state of the ovaries and of the fat body were determined. In addition, the relative increase in weight was calculated by the formula $D=\left(W_{2}-W_{1}\right) / W_{1}$, where $W_{1}$ is the initial weight of a female at the beginning of the experiment (just after emergence) and $W_{2}$ is its weight at the end of the experiment (before dissection). Further, the age at the moment of the beginning of oviposition was recorded for 
each ovipositing female. In total, 249 females were used in the study (from 18 to 24 per each of the 12 experimental treatments).

Statistical treatment of the experimental results included multiple linear regression, probit analysis, Spearman rank correlation analysis, and $\chi^{2}$ test. For the descriptive statistics, the mean and standard error were used. All these calculations were conducted with SYSTAT 10.2 software.

\section{RESULTS}

Total survival rate of $C h$. sexmaculata females during the experiment $\left(10\right.$ and 15 days at 24 and $20^{\circ} \mathrm{C}$, correspondingly) was rather high $(93.2 \%, n=249)$ and was not dependent on temperature or photoperiod (Table 1) but increased with the initial weight of female. In addition, survival with feeding on aphids was higher than that with feeding on grain moth eggs (99.2 and 87.8\%, correspondingly).

Analysis of the results of dissection showed that most females had well developed ovaries and undeveloped fat body (Table 2). These females, as well as a few individuals with well developed ovaries and well developed fat body, were considered as reproductively active, whereas females with undeveloped ovaries and well developed fat body were considered as diapausing. Sporadic females with undeveloped ovaries and undeveloped fat body were excluded from further analysis. In total, the rates of development of ovaries and fat body were strongly negatively correlated $\left(\chi^{2}=71.2, d f=1\right.$, $p<0.001$; the Spearman rank correlation coefficient $R=-0.55)$.

The proportion of diapausing females was dependent only on the temperature (Table 1), being equal to 0.8 and $7.4 \%$ at 24 and $20^{\circ} \mathrm{C}$, correspondingly. However, not all females which were reproductively active at the moment of dissection, started oviposition during the experiment (i. e. during 10 and 15 days at temperatures of 24 and $20^{\circ} \mathrm{C}$, correspondingly). The proportion of individuals which started to lay eggs was equal to $80.7 \%$ of reproductively active females (or $77.5 \%$ of the total sample) and was significantly dependent only on diet (Table 1): 95.7 and $58.2 \%$ of the females started oviposition during the experiment with feeding on aphids and on the grain moth eggs, correspondingly. The mean age of the females at the moment of laying of the first egg, on the contrary, significantly depended both on the temperature $\left(5.9 \pm 0.2\right.$ and $8.5 \pm 0.3$ days at 24 and $20^{\circ} \mathrm{C}$, correspondingly) and on the diet (6.0 \pm 0.2 and $9.3 \pm 0.3$ days with feeding on aphids and on grain moth eggs, correspondingly) (Table 1). In particular, at $20^{\circ} \mathrm{C}$ oviposition was started by $86 \%$ of females with developed ovaries and undeveloped fat body but only by $50 \%$ of females in which both ovaries and fat body were well developed at the moment of dissection (the difference is statistically significant: $\chi^{2}=5.5, d f=1, p=0.019$ ).

The relative increase in body weight of the Ch. sexmaculata females during the experiment depended neither on the temperature nor on the photoperiod but was strongly negatively correlated with the initial body weight (Table 1). In addition, the relative increase in body weight was significantly dependent on the diet (59.0 and $41.9 \%$ with feeding on aphids and on grain moth eggs, correspondingly). Further, the mean relative increase in the body weight of reproductively active females $(52.3 \%)$ was significantly (Table 1$)$ higher than that of diapausing females $(29.0 \%)$.

\section{DISCUSSION}

Taking into account the influence of temperature and nutritional value of food (aphid species), the mean age of Ch. sexmaculata females at the beginning of oviposition which was recorded in our experiment is close to the results of the previous studies: 3.2 days (Omkar et al., 2005), from 4.9 to 9.2 days depending on the photoperiod (Wang et al., 2013), 8.8 days (Zhao et al., 2015) at $25^{\circ} \mathrm{C}, 5.6$ days at $27^{\circ} \mathrm{C}$ (Campbell et al., 1980), and from 2.7 to 4.1 days depending on food at $27.5^{\circ} \mathrm{C}$ (Mirhosseini et al., 2015). Besides, in our study, about $20 \%$ of females which were reproductively active at the moment of dissection did not start to lay eggs during the experiment. These data suggest that the continuation of the experiment would likely result in an increase of the pre-oviposition period.

However, the few females which were classified as diapausing based on the results of dissection should in no way be considered as merely delaying the beginning of oviposition for a long time. First, the arrest of ovary development in these females is accompanied with the development of the fat body which is known as the main sign of reproductive diapause in insects (Zaslavsky, 1984; Tauber et al., 1986; Saulich and Volkovich, 2004; Danks, 2007) and, particularly, in Coccinellidae (Hodek, 
Table 1. The influence of temperature, photoperiod, diet, and initial weight on survival, beginning of oviposition, and weight dynamics of Cheilomenes sexmaculata (Fabricius) females

\begin{tabular}{|c|c|c|c|c|c|}
\hline Factor & $\begin{array}{l}\text { Female survival } \\
\qquad(n=249)^{1}\end{array}$ & $\begin{array}{l}\text { The proportion of } \\
\text { diapausing females } \\
\quad(n=227)^{1}\end{array}$ & $\begin{array}{l}\text { The proportion } \\
\text { of females which } \\
\text { started to lay eggs } \\
\qquad(n=227)^{1}\end{array}$ & $\begin{array}{l}\text { Female age at } \\
\text { the beginning of } \\
\text { oviposition } \\
(n=176)^{2}\end{array}$ & $\begin{array}{l}\text { The relative increase } \\
\text { in female weight } \\
\quad(n=227)^{2}\end{array}$ \\
\hline Temperature & $\begin{array}{c}C=0.122 \pm 0.088 \\
p=0.111\end{array}$ & $\begin{array}{c}C=-0.292 \pm 0.128 \\
p=0.023\end{array}$ & $\begin{array}{c}C=-0.020 \pm 0.058 \\
p=0.727\end{array}$ & $\begin{array}{c}C=-0.723 \pm 0.077 \\
p<0.001\end{array}$ & $\begin{array}{c}C=-0.887 \pm 0.548 \\
p=0.107\end{array}$ \\
\hline Photoperiod & $\begin{array}{c}C=0.014 \pm 0.089 \\
p=0.878\end{array}$ & $\begin{array}{c}C=0.057 \pm 0.117 \\
p=0.625\end{array}$ & $\begin{array}{c}C=-0.017 \pm 0.064 \\
p=0.790\end{array}$ & $\begin{array}{c}C=-0.008 \pm 0.082, \\
p=0.919\end{array}$ & $\begin{array}{c}C=0.762 \pm 0.579 \\
p=0.190\end{array}$ \\
\hline Diet & $\begin{array}{c}C=-1.320 \pm 0.427, \\
p=0.002\end{array}$ & $\begin{array}{c}C=4.23 \pm 52.49, \\
p=0.936\end{array}$ & $\begin{array}{c}C=-1.516 \pm 0.239 \\
p<0.001\end{array}$ & $\begin{array}{c}C=3.329 \pm 0.281 \\
p<0.001\end{array}$ & $\begin{array}{c}C=-14.37 \pm 1.93 \\
p<0.001\end{array}$ \\
\hline $\begin{array}{l}\text { Initial female } \\
\text { weight }\end{array}$ & $\begin{array}{c}C=0.243 \pm 0.112 \\
p=0.030\end{array}$ & $\begin{array}{c}C=0.027 \pm 0.123 \\
p=0.824\end{array}$ & $\begin{array}{c}C=-0.014 \pm 0.067 \\
p=0.836\end{array}$ & $\begin{array}{c}C=0.219 \pm 0.089 \\
p=0.015\end{array}$ & $\begin{array}{c}C=-2.238 \pm 0.613 \\
p<0.001\end{array}$ \\
\hline $\begin{array}{l}\text { Induction } \\
\text { of diapause }\end{array}$ & - & - & - & - & $\begin{array}{c}C=-18.739 \pm 5.027, \\
p=0.002\end{array}$ \\
\hline
\end{tabular}

${ }^{1}$ Probit analysis results: regression coefficient $C$, its standard error, and the significance of influence $p$.

${ }^{2}$ Regression analysis results: regression coefficient $C$, its standard error, and the significance of influence $p$.

2012). Second, the proportion of diapausing individuals depends only on the temperature, whereas the proportion of females which started to lay eggs significantly depends on the diet. Moreover, the age at the beginning of oviposition also depends on the female's weight. This difference between the responses to environmental factors suggests corresponding difference between the mechanisms of the reactions. Females which at the end of the experiment have not only developed ovaries but also a developed fat body significantly less often started oviposition during the test. Probably, these (relatively few) individuals started to enter diapause but then switched the program of development and, although with some delay, started reproductive maturation.

Taken together, these data suggest that some of Ch. sexmaculata females not merely delay maturation but enter a qualitatively different state: reproductive dia- pause, although this diapause is induced only in a small fraction of individuals and, besides, it is very unstable (easily reversible). Such a relatively short-term and easily reversible reproductive diapause was also recorded in some other predatory coccinellids (Hodek and Iperti, 1983; Reznik and Vaghina, 2006; Hodek, 2012; Reznik et al., 2015a). Earlier studies conducted on subtropical populations of some other insect species from different taxa also showed that even under the most "strong" combination of diapause-inducing factors, not all but only a certain, sometimes relatively small fraction of individuals entered diapause (Pullin and Knight, 1992; Sota, 1994; Shimizu and Kawasaki, 2001; Schmidt et al., 2005; Musolin and Ito, 2008).

External manifestations of reproductive diapause in Ch. sexmaculata, as can be seen from the results of our study, are limited to the termination of oviposition: the

Table 2. Correlation between ovary and fat body development in Cheilomenes sexmaculata (Fabricius) females (percentage of the total number of dissected individuals, $n=232$ )

\begin{tabular}{l|c|c}
\hline \multirow{2}{*}{ Ovaries } & \multicolumn{2}{|c}{ Fat body } \\
\cline { 2 - 3 } & undeveloped & developed \\
\hline Undeveloped & $2.2 \%$ - excluded from further analysis & $3.9 \%$ - diapausing \\
Developed & $90.5 \%$ - reproductively active & $3.4 \%$ - reproductively active \\
\hline
\end{tabular}


weight of females not only does not increase, as is often the case with reproductive diapause in other Coccinellidae species (Reznik and Vaghina, 2006; Hodek, 2012; Reznik et al., 2015b; Ovchinnikova et al., 2016), but, on the contrary, significantly decreases. Obviously, in this case, induction of diapause is accompanied not by accumulation but only by the redistribution of resources, and the growth of the fat body occurs only due to the cessation of the ovary growth and development.

In our study, the ability to enter reproductive diapause was observed only in a very small fraction of the laboratory population of a predatory ladybird Ch. sexmaculata. In a subtropical monsoon climate, the adaptive value of this ability, judging by the small number of individuals possessing it, is not high. Possibly, the termination of oviposition saves resources during the winter drought that is characteristic of this type of climate. However, upon dispersal to the north, to colder regions, the ability to enter winter diapause becomes highly adaptive and, judging by the studies carried out in Japan (Kawakami et al., 2016, 2017), is already found in all or at least in most individuals of Ch. sexmaculata. Thus, the ability of some individuals to enter reproductive diapause was probably an essential prerequisite for the natural expansion of the species range.

\section{ACKNOWLEDGMENTS}

We are deeply grateful to L.S. Ramenskaya and T.Ya. Umarova (Zoological Institute RAS) for assistance in conducting experiments.

\section{FUNDING}

The study was supported by a research grant RSF 20-6647010 from the Russian Science Foundation.

\section{COMPLIANCE WITH ETHICAL STANDARDS}

The authors declare that they have no conflict of interest. All the applicable international, national, and institutional guidelines for the care and use of animals were followed. All the procedures performed in studies involving animals were in accordance with the ethical standards of the institution or practice at which the studies were conducted.

\section{OPEN ACCESS}

This article is licensed under a Creative Commons Attribution 4.0 International License, which permits use, sharing, adaptation, distribution and reproduction in any medium or format, as long as you give appropriate credit to the original author(s) and the source, provide a link to the Creative Commons licence, and indicate if changes were made. The images or other third party material in this article are included in the article's Creative Commons licence, unless indicated otherwise in a credit line to the material. If material is not included in the article's Creative Commons licence and your intended use is not permitted by statutory regulation or exceeds the permitted use, you will need to obtain permission directly from the copyright holder. To view a copy of this licence, visit http://creativecommons.org/licenses/by/4.0/.

\section{REFERENCES}

Campbell, R.K., Farris, T.N., Perring, T.M., Leonard, M.E., Cartwright, B.O., and Eikenbary, R.D., Biological observations of Menochilus sexmaculatus reared on Schizaphis graminum, Ann. Entomol. Soc. Amer., 1980, vol. 73, no. 2, p. 153. https://doi.org/10.1093/aesa/73.2.153

Danilevsky, A.S., Photoperiodism i sezonnoe razvitie naseko$m y k h$ (Photoperiodism and Seasonal Development of Insects), Leningrad: Leningrad State University, 1961.

Danks, H.V., The elements of seasonal adaptations in insects, Canad. Entomol., 2007, vol. 139, no. 1, p. 1.

https://doi.org/10.4039/n06-048

Denlinger, D.L., Regulation of diapause, Ann. Rev. Entomol., 2002, vol. 47, p. 93.

https://doi.org/10.1146/annurev.ento.47.091201.145137

Hodek, I., Diapause / Dormancy, in Ecology and Behaviour of the Ladybird Beetles (Coccinellidae), Hodek, I., van Emden, H.F., and Honěk, A., Eds., Chichester: Wiley-Blackwell, 2012, p. 275.

Hodek, I. and Iperti, G., Sensitivity to photoperiod in relation to diapause in Semiadalia undecimnotata females, Entomol. Exp. Appl., 1983, vol. 34, no. 1, p. 9.

https://doi.org/10.1111/j.1570-7458.1983.tb03283.x

Iftikhar, A., Aziz, M.A., Naeem, M., Ahmad, M., and Mukhtar, T., Effect of temperature on demography and predation rate of Menochilus sexmaculatus (Coleoptera: Coccinellidae) reared on Phenacoccus solenopsis (Hemiptera: Pseudococcidae), Pakistan J. Zool., 2018, vol. 50, no. 5, p. 1885.

Kawakami, Y., Yamazaki, K., and Ohashi, K., Population dynamics, seasonality and aphid prey of Cheilomenes sexmaculata (Coleoptera: Coccinellidae) in an urban park in central Japan, Eur. J. Entomol., 2016, vol. 113, p. 192.

https://doi.org/10.14411/eje.2016.023

Kawakami, Y., Yamazaki, K., and Ohashi, K., Protogyny after hibernation and aestivation in Cheilomenes sexmaculata (Coleoptera: Coccinellidae) in central Japan, Eur. J. Entomol., 
2017, vol. 114, p. 275.

https://doi.org/10.14411/eje.2017.033

Mirhosseini, M.A., Hosseini, M.R., and Jalali, M.A., Effects of diet on development and reproductive fitness of two predatory coccinellids (Coleoptera: Coccinellidae), Eur. J. Entomol., 2015, vol. 112, no. 3, p. 446.

https://doi.org/10.14411/eje.2015.051

Musolin, D.L. and Ito, K., Photoperiodic and temperature control of nymphal development and induction of reproductive diapause in two predatory Orius bugs: interspecific and geographic differences, Physiol. Entomol., 2008, vol. 33, no. 4 , p. 291.

https://doi.org/10.1111/j.1365-3032.2008.00628.x

Omkar, Mishra, G., and Singh, K. Effects of different wavelengths of light on the life attributes of two aphidophagous ladybirds (Coleoptera: Coccinellidae), Eur. J. Entomol., 2005, vol. 102 , no. 1 , p. 33.

https://www.eje.cz/pdfs/eje/2005/01/05.pdf

Ovchinnikova, A.A., Ovchinnikov, A.N., Reznik, S.Ya., Dolgovskaya, M.Yu., and Belyakova, N.A., Weight dynamics in females of invasive and autochthonous populations of Harmonia axyridis (Pallas) (Coleoptera, Coccinellidae) during the induction of reproductive diapause, Entomol. Obozr., 2016, vol. 95, no. 4, p. 717.

Pandi, G., Paul, B., Vivek, S., and Shankarganesh, K., Feeding potential and biology of coccinellid predator Cheilomenes sexmaculata (Fabricius) (Coleoptera) on aphid hosts, Indian J. Entomol., 2012, vol. 74, no. 4, p. 388.

Pullin, A.S. and Knight, T.M., Induction and termination of reproductive diapause in a neotropical beetle, Chelymorpha alternans (Coleoptera: Chrysomelidae), J. Zool., 1992, vol. 227, no 3, p. 509.

https://doi.org/10.1111/j.1469-7998.1992.tb04411.x

Reznik, S.Ya. and Vaghina, N.P., Dynamics of fat content during the induction and termination of "trophic diapause" in Harmonia sedecimnotata Fabr. (Coleoptera, Cocinellidae) females, Entomol. Obozr., 2006, vol. 85, no. 1, p. 3.

Reznik, S.Ya., Dolgovskaya, M.Yu., Ovchinnikov, A.N., and Belyakova, N.A., Weak photoperiodic response facilitates the biological invasion of the harlequin ladybird Harmonia axyridis (Pallas) (Coleoptera: Coccinellidae), J. Appl. Entomol., 2015a, vol. 139, no. 4, p. 241.

https://doi.org/10.1111/jen.12158

Reznik, S.Ya., Dolgovskaya, M.Y., and Ovchinnikov, A.N., Effect of photoperiod on adult size and weight in Harmonia axyridis (Coleoptera: Coccinellidae), Eur. J. Entomol., 2015b, vol. 112, no. 4, p. 642.

https://doi.org/10.14411/eje.2015.081

Saulich, A.Kh., Sezonnoe razvitie nasekomykh $i$ vozmozhnosti ikh rasseleniya (Seasonal Developemnt of Insects and Possi- bilities of Their Dispersal), St. Petersburg: St. Petersburg State University, 1999.

Saulich, A.Kh. and Volkovich, T.A., Ekologiya fotoperiodizma nasekomykh (Ecology of Photoperiodism in Insects), St. Petersburg: St. Petersburg State University, 2004.

Saunders, D.S., Steel, C.G.H., Vafopoulou, X., and Lewis, R.D., Insect Clocks, Amsterdam: Elsevier, 2002.

Schmidt, P.S., Matzkin, L., Ippolito, M., and Eanes, W.F., Geographic variation in diapause incidence, life-history traits, and climatic adaptation in Drosophila melanogaster, Evolution, 2005, vol. 59, no. 8, p. 1721-1732.

https://doi.org/10.1111/j.0014-3820.2005.tb01821.x

Shimizu, T. and Kawasaki, K., Geographic variability in diapause response of Japanese Orius species, Entomol. Exp. Appl., 2001, vol. 98, no. 3, p. 303.

Singh, N. and Mishra, G., Effect of photoperiod on slow and fast developing individuals in aphidophagous ladybirds, Menochilus sexmaculatus and Propylea dissecta (Coleoptera: Coccinellidae), Insect Sci., 2016. vol. 23, no. 1, p. 117. https://doi.org/10.1111/1744-7917.12182

Sota, T., Larval diapause, size, and autogeny in the mosquito Aedes togoi (Diptera, Culicidae) from tropical to subarctic zones, Canad. J. Zool., 1994, vol. 72, no. 8, p. 1462. https://doi.org/10.1139/z94-193

Tauber, M.J., Tauber, C.A., and Masaki, S., Seasonal Adaptations of Insects, New York: Oxford University Press, 1986.

Tougeron, K., Diapause research in insects: historical review and recent work perspectives, Entomol. Exp. Appl., 2019, vol. 167 , no. 1, p. 27.

https://doi.org/10.1111/eea.12753

Wang, S., Tan, X.L., Guo, X.J., and Zhang, F., Effect of temperature and photoperiod on the development, reproduction, and predation of the predatory ladybird Cheilomenes sexmaculata (Coleoptera: Coccinellidae), J. Econ. Entomol., 2013, vol. 106 , no. 6 , p. 2621.

https://doi.org/10.1603/EC13095

Zaslavsky, V.A., Fotoperiodicheskii i temperaturnyi kontrol' razvitiya nasekomykh (Photoperiodic and Temperature Control of Insect Development), Leningrad: Nauka, 1984.

Zaslavsky, V.A., The diversity of environmental factors controlling insect seasonal development and the possible unity of underlying physiological mechanism, Entomol. Obozr., 1996, vol. 75 , no. 2 , p. 233.

Zhao, J., Li, S., Gao, X.W., Zhang, F., and Wang, S., Comparison of life tables of Cheilomenes sexmaculata (Coleoptera: Coccinellidae) under laboratory and greenhouse conditions, J. Econ. Entomol., 2015, vol. 108, no. 4, p. 1700.

https://doi.org/10.1093/jee/tov 178 